\title{
Intestinal Pseudo-Obstruction as an Initial Manifestation of Systemic Lupus Erythematosus
}

\author{
Dong Jun Oh*, Jae Nam Yang*, Yun Jeong Lim, Ji Hyuk Kang, Jung Hyun Park, Mal Young Kim \\ Division of Gastroenterology, Department of Internal Medicine, Dongguk University Ilsan Hospital, Dongguk University College of Medicine, \\ Goyang, Korea
}

Intestinal pseudo-obstruction (IPO) is an uncommon, severe complication that occurs in a small subgroup of patients with systemic lupus erythematosus (SLE). To our knowledge, approximately 30 cases of IPO in SLE have been reported in the literature. Moreover, IPO is rare as an initial manifestation of SLE. We report a case of a 43-year-old woman with SLE who initially presented with IPO. (Intest Res 2015;13:282-286)

Key Words: Intestinal pseudo-obstruction; Lupus erythematosus, systemic

\section{INTRODUCTION}

Intestinal pseudo-obstruction (IPO) is characterized by ineffective intestinal propulsion without mechanical or obstructive factors. Its clinical manifestations include nausea, vomiting, dysphagia, abdominal distension, abdominal pain, constipation, and weight loss. It is also characterized by sluggish or no audible bowel sounds and multiple air-fluid levels on abdominal radiography. ${ }^{1}$ It may also be the primary or secondary manifestation of other diseases, including nervous, endocrine, and metabolic disorders, intra-abdominal inflammation, and connective tissue disease. ${ }^{2}$ Systemic lupus erythematosus (SLE) is a multisystemic, autoimmune inflammatory disease of unknown etiology, and may affect any part of the gastrointestinal (GI) tract, from the mouth to the rectum. It has been reported that mild GI symptoms such as nausea, vomiting, and abdominal discomfort oc-

Received September 1, 2014. Revised October 31, 2014

Accepted November 20, 2014.

Correspondence to Yun Jeong Lim, Division of Gastroenterology,

Department of Internal Medicine, Dongguk University IIsan Hospital,

Dongguk University College of Medicine, 27 Dongguk-ro, Ilsandong-gu,

Goyang 410-773, Korea. Tel: +82-31-961-7133, Fax: +82-31-961-7753,

E-mail: limyJ@Dongguk.ac.kr

*Both authors contributed equally to this work.

Financial support: None. Conflict of interest: None. cur in more than $50 \%$ of patients with SLE. ${ }^{2,3}$ However, IPO remains rare in SLE. To our knowledge, only a few cases of IPO appearing as the initial presentation of SLE have been reported. ${ }^{4}$

We report an interesting case of SLE in a 43-year-old woman who initially presented with IPO.

\section{CASE REPORT}

A 43-year-old woman suddenly developed fever at a body temperature of $39.1^{\circ} \mathrm{C}$ and leukopenia. Fever spontaneously subsided after 3 days. She gradually developed nausea and could not eat due to severe vomiting. She had no spontaneous bowel movement and did not notice passage of flatus for nearly a week. She had weight loss of 4-5 kg in 2 weeks.

She had no prior history of cancer, metabolic or neurological diseases, trauma, or abdominal or pelvic surgery. She was taking no medications. At admission, vital signs were blood pressure of 106/72 $\mathrm{mm} \mathrm{Hg}$, pulse rate of 75 beats/min, respiratory rate of 20 breaths/min, and body temperature of $39.1^{\circ} \mathrm{C}$. She had normal hair distribution, no skin rash, and no palpable superficial lymph nodes. Headache, photosensitivity, oral ulceration, and arthralgia were not evident. The abdomen was soft and markedly distended, with no audible bowel sounds. She had focal tenderness in the epigastrium.

๑ Copyright 2015. Korean Association for the Study of Intestinal Diseases. All rights reserved.

This is an Open Access article distributed under the terms of the Creative Commons Attribution Non-Commercial License (http://creativecommons.org/licenses/by-nc/4.0)

which permits unrestricted non-commercial use, distribution, and reproduction in any medium, provided the original work is properly cited. 
Laboratory test results showed a hemoglobin level of 11.0 $\mathrm{g} / \mathrm{dL}$, white blood cell count of $2,710 / \mathrm{mm}^{3}$ (absolute neutrophil count: $1,951 / \mathrm{mm}^{3}$ and lymphocytes: $216 / \mathrm{mm}^{3}$ ) and platelet count of $118,000 / \mathrm{mm}^{3}$. Creatinine level was $0.44 \mathrm{mg} /$ $\mathrm{dL}$; sodium level, $138 \mathrm{mmol} / \mathrm{L}$; potassium level, $2.7 \mathrm{mmol} /$ $\mathrm{L}$; and chloride level, $109 \mathrm{mmol} / \mathrm{L}$. She had normal thyroid function. Her fasting glucose level and high sensitivity CRP values were normal. Antinuclear antibody (titer of 1:1280 with speckled pattern) was positive. Anti-Ro antibody, antiLa antibody, and anti-Ro52 antibody $(3+, 1+, 3+$, respectively) were positive. Anti-Smith antibody, rheumatoid factor, anti-cardiolipin antibody, anti- $\beta 2$-glycoprotein I ( $\beta 2$-GPI) antibody, and the direct Coombs test result were negative.

The urinalysis result was normal. The stool white blood cell count was 0-1/low-power field. Stool bacterial culture, and tests results for adenovirus, astrovirus, norovirus, enterovirus, and rotavirus by PCR were all negative. Marked gaseous dilatation and air-fluid levels were observed on plain abdominal radiography (Fig. 1A). An abdominal and pelvic CT scan showed a small amount of ascites, mild intrahepatic duct dilatation, and marked distension of the small bowel without a definite obstructive lesion. No evidence of ureterohydronephrosis or peritonitis was observed (Fig. 1B). She had no notable findings on esophagogastroduodenoscopy and colonoscopy. Capsule endoscopy was performed. No mucosal lesion in the small bowel was observed. Small bowel transit time was nearly 10 hours, and passage of the capsule occurred after 3 days. Despite several positive autoimmune serologic markers, clinical manifestations did not meet the diagnostic criteria for autoimmune diseases, such as systemic sclerosis, SLE, or Sjögren syndrome.
She had slight improvement with conservative care, including hydration and intravenous metoclopramide, throughout the 18-day hospitalization course. On the 14th day following discharge, she presented with recurrent nausea and abdominal distension. Severe small bowel dilatation and air-fluid levels were present on a plain abdominal radiography. Because we could not completely rule out the possibility of secondary IPO due to autoimmune diseases such as SLE, she was given oral prednisolone $40 \mathrm{mg} /$ day (about 1 $\mathrm{mg} / \mathrm{kg}$ ) for 7 days. She stopped oral prednisolone because of adverse effects including suicidal ideation and hair loss. The oral steroid trial failed to improve the symptoms, as demonstrated on radiography (Fig. 1C), and was discontinued. Oral pyridostigmine $60 \mathrm{mg} /$ day was administered, but the radiographic finding did not improve. With oral prokinetics only, the ileus gradually improved on radiography (Fig. 1D).

Forty-five days following discharge, she came to the hospital due to oral ulcers. Four months later, she developed arthralgias of the knees, elbows, wrists, and shoulders. She was finally diagnosed with SLE according to positive serology and overall clinical manifestations. Oral steroids were recommended but refused. She did take oral prokinetics and non-steroidal anti-inflammatory drugs (Table 1).

\section{DISCUSSION}

IPO is characterized by ineffective intestinal propulsion resulting from impaired functioning of the visceral smooth muscle, enteric nerves, or visceral autonomic nervous system. ${ }^{2}$ The classic symptoms of IPO include abdominal pain, abdominal distension, nausea, vomiting, alternating diarrhea
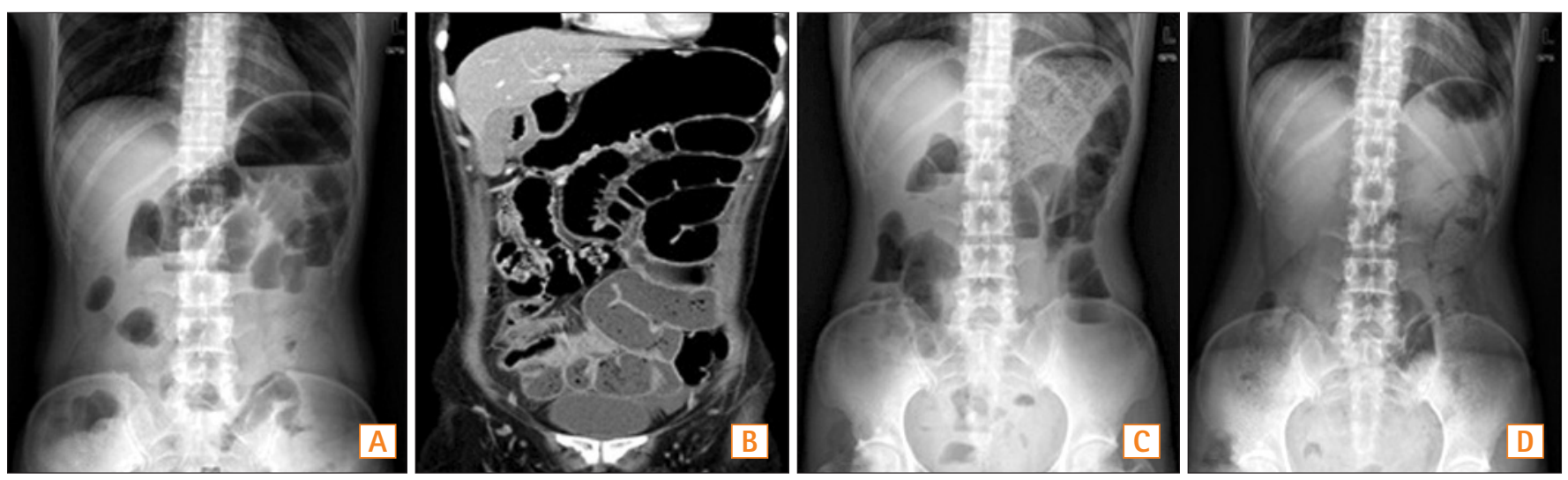

Fig. 1. Radiological findings according to clinical course. At admission, she had nausea, vomiting, obstipation, and abdominal discomfort. (A) Plain abdominal radiography showed gaseous dilatation and air-fluid levels in small bowel loops. (B) Coronal CT image showed marked diffuse distension of the small bowel without a definite obstructive lesion. (C) Fourteen days following discharge, she presented with recurrent nausea and abdominal distension. Steroid was administered. Plain abdominal radiography showed the residual presence of the gaseous distension despite steroid therapy. (D) Four months later, plain abdominal radiography showed improvement of the gaseous distension. 
Table 1. Clinical Course of the Present Case

\begin{tabular}{|c|c|c|}
\hline Time & Clinical symptoms & Treatment \\
\hline During the 18 -day hospitalization & $\begin{array}{l}\text { Nausea, vomiting, obstipation, and abdominal } \\
\text { discomfort }\end{array}$ & $\begin{array}{l}\text { Hydration, Levin tube insertion, and intravenous } \\
\text { metoclopramide }\end{array}$ \\
\hline 14 days following discharge & $\begin{array}{l}\text { Aggravated symptoms, such as nausea, anorexia, } \\
\text { and postprandial abdominal distension }\end{array}$ & $\begin{array}{l}\text { (1) Initiation of oral prednisolone ( } 40 \mathrm{mg} / \text { day) for } 7 \text { days } \\
\text { (2) Maintenance of oral prokinetics }\end{array}$ \\
\hline 1 mo following discharge & $\begin{array}{l}\text { (1) No improvement on plain abdominal radiography } \\
\text { (2) Adverse effects of steroid therapy, including suicidal } \\
\text { ideation and hair loss }\end{array}$ & $\begin{array}{l}\text { (1) Discontinuation of oral prednisolone } \\
\text { (2) Introduction of oral pyridostigmine (60 mg/day) } \\
\text { (3) Maintenance of oral prokinetics }\end{array}$ \\
\hline 45 days following discharge & $\begin{array}{l}\text { (1) Residual abdominal discomfort and obstipation } \\
\text { (2) The occurrence of oral ulcer }\end{array}$ & $\begin{array}{l}\text { (1) Refusal to take oral prednisolone } \\
\text { (2) Maintenance of oral prokinetics }\end{array}$ \\
\hline 4 mo following discharge & $\begin{array}{l}\text { (1) Improvement of GI symptoms } \\
\text { (2) Arthralgias of multiple joints (knee, wrist, elbow } \\
\text { and shoulder) }\end{array}$ & $\begin{array}{l}\text { (1) Maintenance of oral prokinetics } \\
\text { (2) NSAIDS for arthralgias }\end{array}$ \\
\hline
\end{tabular}

$\mathrm{Gl}$ gastrointestinal.

and constipation, and weight loss. Paradoxically, both constipation and diarrhea may be observed in patients with IPO. Small bowel involvement may lead to bacterial overgrowth and steatorrhea, while predominant colonic involvement leads to constipation.-7

The diagnosis of IPO is made based on clinical aspects. Multiple air-fluid levels and small bowel dilatation, with or without thickened bowel wall, were observed on radiological imaging. esophagogastroduodenoscopy, colonoscopy, and abdominal CT are needed to exclude mechanical obstruction or elucidate other diseases. ${ }^{3}$ Progressive systemic sclerosis, mixed connective tissue disease, and polymyositis/ dermatomyositis are known secondary causes of IPO. ${ }^{8}$ IPO occurs in patients with SLE. ${ }^{1-4,7,8}$ It has also been reported that mild GI complications occur commonly in more than $50 \%$ of patients with SLE. ${ }^{6,9}$ SLE may affect any part of the GI tract, from the mouth to the rectum. IPO is a rare GI manifestation of SLE. To our knowledge, there have been about 30 cases of IPO in SLE reported in the literature. As shown in the current case, it may also occur as the initial presentation of SLE (Table 2). ${ }^{4,10-15} \mathrm{Kim}$ J and Kim N reported that a diagnosis of IPO was made in patients with SLE who underwent subtotal colectomy. ${ }^{12}$ It would be possible to avoid unnecessary surgery if clinicians made a diagnosis of IPO in SLE at the earliest possible opportunity.

Little is known about the precise pathophysiology by which IPO occurs in patients with SLE, but there are numerous hypotheses. One is that IPO in SLE might be a late manifestation of immune-complex-mediated vasculitis. ${ }^{8}$ In SLE, a distinct subset of proinflammatory neutrophils induces vascular damage. Visceral smooth muscle damage and resultant dysmotility are induced by vasculitis. ${ }^{2,6}$ Smooth muscle dysfunction induced by vasculitis may be more diffuse and involve the ureterovesical or hepatobiliary systems. Mok et al. reported the coexistence of small bowel hypomotility and ureterohydronephrosis in 12 of 18 patients. ${ }^{1}$ In addition, Chen et al. observed the presence of a distended common bile duct without any evidence of mechanical obstruction with IPO in patients with SLE. ${ }^{16}$ However, no histopathologic evidence of vasculitis was found in some cases of IPO in SLE. ${ }^{1,17,18}$ Another pathophysiological mechanism of IPO is an intrinsic muscle dysmotility. Postmortem examination showed an extensive fibrotic process in the muscularis layer without abnormality of innervation. ${ }^{19}$ This might be a myogenic type of IPO. ${ }^{19}$

IPO can present with active lupus serologies. A previous study reported that the positive rates of anti-Ro (83.9\%) and anti-La antibody (75\%) are significantly higher in IPO than the usual prevalences of anti-Ro (30\%) and anti-La antibody (10\%) in SLE. ${ }^{1}$ The current case presented with positive antiRo and anti-La antibody. Anti-proliferative cell nuclear antigen antibody was also more frequently detected in the patients with than in those without IPO. ${ }^{20}$ However, no specific autoantibodies definitely related to IPO were found in the patients with SLE. It is necessary to identify specific antibodies that cause smooth muscle injury.

Although the pathogenic mechanisms have not been clarified, high-dose steroids are helpful in improving the symptoms of IPO in SLE. ${ }^{2,716}$ Intravenous methylprednisolone initiated at $1 \mathrm{mg} / \mathrm{kg} /$ day for 3 days, followed by oral prednisone $1 \mathrm{mg} / \mathrm{kg} /$ day resulted in a good clinical response in most cases. ${ }^{2.8}$ In this case, the therapeutic effect of oral prednisone could not be evaluated due to poor compliance induced by side effects. Immunosuppressants, such as azathioprine, 
Table 2. Reported Cases of Intestinal Pseudo-Obstruction (IPO) as Initial Manifestation of Systemic Lupus Erythematosus

\begin{tabular}{|c|c|c|c|c|c|}
\hline Study & Sex & Age & IPO manifestation & Extra-GI manifestation & Management \\
\hline Ahn et al..$^{10}$ & Female & 26 & $\begin{array}{l}\text { Nausea, vomiting, ascites } \\
\text { Peritonitis }\end{array}$ & $\begin{array}{l}\text { Pleural effusion } \\
\text { Ureterohydronephrosis } \\
\text { Leukopenia and proteinuria }\end{array}$ & $\begin{array}{l}\text { Exploratory laparotomy } \\
\text { Steroid } \\
\text { Azathioprine }\end{array}$ \\
\hline Cho et al." & Female & 13 & $\begin{array}{l}\text { Nausea, vomiting, ascites } \\
\text { Abdominal pain }\end{array}$ & $\begin{array}{l}\text { Multiple finger nodules } \\
\text { Pleural effusion } \\
\text { Ureterohydronephrosis } \\
\text { Lymphopenia }\end{array}$ & Steroid \\
\hline Kim J and Kim N ${ }^{12}$ & Male & 20 & Vomiting, abdominal pain & $\begin{array}{l}\text { Dysuria } \\
\text { Proteinuria } \\
\text { Hydronephrosis }\end{array}$ & $\begin{array}{l}\text { Subtotal colectomy } \\
\text { Steroid } \\
\text { Azathioprine }\end{array}$ \\
\hline Ceccato et al. ${ }^{4}$ & Female & 49 & $\begin{array}{l}\text { Vomiting, ascites } \\
\text { Abdominal pain, diarrhea }\end{array}$ & $\begin{array}{l}\text { Pleural effusion } \\
\text { Lymphopenia } \\
\text { Leukopenia }\end{array}$ & Steroid \\
\hline Zhang et al. $^{13}$ & Female & 48 & $\begin{array}{l}\text { Vomiting and ascites } \\
\text { Abdominal pain } \\
\text { Constipation } \\
\text { Peritonitis }\end{array}$ & $\begin{array}{l}\text { Pleural effusion } \\
\text { Fever and weight loss } \\
\text { Hydronephrosis }\end{array}$ & Steroid \\
\hline Khairullah et al. ${ }^{14}$ & Female & 42 & $\begin{array}{l}\text { Nausea, vomiting, ascites } \\
\text { Diarrhea }\end{array}$ & $\begin{array}{l}\text { Hydronephrosis } \\
\text { Thrombocytopenia } \\
\text { Hemolytic anemia }\end{array}$ & $\begin{array}{l}\text { Exploratory laparotomy } \\
\text { Steroid } \\
\text { Azathioprine } \\
\text { Hydroxychloroquine }\end{array}$ \\
\hline García López et al. $^{15}$ & Female & 27 & $\begin{array}{l}\text { Abdomen pain, ascites } \\
\text { Dysphagia }\end{array}$ & $\begin{array}{l}\text { Malar erythema } \\
\text { Seizures and weight loss } \\
\text { Pleural effusion } \\
\text { Dysuria and proteinuria } \\
\text { Hemolytic anemia } \\
\text { Sepsis }\end{array}$ & $\begin{array}{l}\text { Exploratory laparotomy } \\
\text { Steroid } \\
\text { IV lgG }\end{array}$ \\
\hline
\end{tabular}

Gl, gastrointestinal.

cyclosporine, and cyclophosphamide, are effective as maintenance therapy. ${ }^{4}$ Prokinetics, such as metoclopramide, itopride, and erythromycin can be helpful. ${ }^{1,8}$ Octreotide is a somatostatin analogue that is effective in improving both clinical symptoms and manometric patterns. ${ }^{1,2}$ Neostigmine or pyridostigmine are parasympathomimetic and reversible cholinesterase inhibitors. ${ }^{16}$ Long-term clinical outcomes vary among patients with SLE who presented with IPO. Narváez et al. analyzed 22 cases of IPO in SLE, reporting that 4 patients died within 6 months after presentation with IPO. ${ }^{8}$ IPO sometimes has an unfavorable prognosis in SLE. Clinicians should be aware of the possibility that IPO may occur as the initial manifestation of SLE.

\section{REFERENCES}

1. Mok MY, Wong RW, Lau CS. Intestinal pseudo-obstruction in systemic lupus erythematosus: an uncommon but important clinical manifestation. Lupus 2000;9:11-18.

2. Perlemuter G, Chaussade S, Wechsler B, et al. Chronic intestinal pseudo-obstruction in systemic lupus erythematosus. Gut 1998;43:117-122.

3. Chng HH, Tan BE, Teh CL, Lian TY. Major gastrointestinal manifestations in lupus patients in Asia: lupus enteritis, intestinal pseudo-obstruction, and protein-losing gastroenteropathy. Lupus 2010;19:1404-1413.

4. Ceccato F, Salas A, Góngora V, et al. Chronic intestinal pseudoobstruction in patients with systemic lupus erythematosus: report of four cases. Clin Rheumatol 2008;27:399-402.

5. Cacoub P, Benhamou Y, Barbet P, et al. Systemic lupus erythematosus and chronic intestinal pseudoobstruction. J Rheumatol 1993;20:377-381. 
6. Nguyen H, Khanna N. Intestinal pseudo-obstruction as a presenting manifestation of systemic lupus erythematosus: case report and review of the literature. South Med J 2004;97:186189.

7. Chen YY, Yen HH, Hsu YT. Intestinal pseudo-obstruction as the initial presentation of systemic lupus erythematosus: the need for enteroscopic evaluation. Gastrointest Endosc 2005;62:984987.

8. Narváez J, Pérez-Vega C, Castro-Bohorquez FJ, Garcia-Quintana AM, Biosca M, Vilaseca-Momplet J. Intestinal pseudo-obstruction in systemic lupus erythematosus. Scand J Rheumatol 2003;32:191-195.

9. Klippel JH. Systemic lupus erythematosus: demographics, prognosis, and outcome. J Rheumatol Suppl 1997;48:67-71.

10. Ahn JK, Koh JH, Jeon CH, Cha HS, Kim YH, Koh EM. A case of intestinal pseudo-obstruction in a patient with systemic lupus erythematosus. J Korean Rheum Assoc 2002;9:313-318.

11. Cho KY, Khil TY, Ahn HM, Lee SW, Seo JW. Intestinal pseudoobstruction as the initial presentation of systemic lupus erythematosus in a 13-year-old girl. Korean J Pediatr 2008;51:655-659.

12. Kim J, Kim N. Intestinal pseudo-obstruction: initial manifestation of systemic lupus erythematosus. J Neurogastroenterol Motil 2011;17:423-424.

13. Zhang J, Fang M, Wang Y, Mao J, Sun X. Intestinal pseudoobstruction syndrome in systemic lupus erythematosus. Lupus 2011;20:1324-1328.
14. Khairullah S, Jasmin R, Yahya F, Cheah TE, Ng CT, Sockalingam S. Chronic intestinal pseudo-obstruction: a rare first manifestation of systemic lupus erythematosus. Lupus 2013;22:957-960.

15. García López CA, Laredo-Sánchez F, Malagón-Rangel J, FloresPadilla MG, Nellen-Hummel H. Intestinal pseudo-obstruction in patients with systemic lupus erythematosus: a real diagnostic challenge. World J Gastroenterol 2014;20:11443-11450.

16. Chen YQ, Xue Q, Wang NS. Visceral muscle dysmotility syndrome in systemic lupus erythematosus: case report and review of the literature. Rheumatol Int 2012;32:1701-1703.

17. Hill PA, Dwyer KM, Power DA. Chronic intestinal pseudoobstruction in systemic lupus erythematosus due to intestinal smooth muscle myopathy. Lupus 2000;9:458-463.

18. Meulders Q, Michel C, Marteau P, et al. Association of chronic interstitial cystitis, protein-losing enteropathy and paralytic ileus with seronegative systemic lupus erythematosus: case report and review of the literature. Clin Nephrol 1992;37:239-244.

19. Nowak TV, Anuras S, Brown BP, Ionasescu V, Green JB. Small intestinal motility in myotonic dystrophy patients. Gastroenterology 1984;86:808-813.

20. Nojima Y, Mimura T, Hamasaki K, et al. Chronic intestinal pseudoobstruction associated with autoantibodies against proliferating cell nuclear antigen. Arthritis Rheum 1996;39:877-879. 